University of Nebraska - Lincoln

DigitalCommons@University of Nebraska - Lincoln

Faculty Papers and Publications in Animal

Science

Animal Science Department

1994

\title{
Uterine Capacity and Ovulation Rate in Mice Selected 21 Generations on Alternative Criteria to Increase Litter Size
}

A. C. Clutter

Oklahoma State University, Stillwater

Y. Kochera Kirby

University of Nebraska-Lincoln

Merlyn K. Nielsen

University of Nebraska-Lincoln, mnielsen1@unl.edu

Follow this and additional works at: https://digitalcommons.unl.edu/animalscifacpub

Part of the Animal Sciences Commons

Clutter, A. C.; Kochera Kirby, Y.; and Nielsen, Merlyn K., "Uterine Capacity and Ovulation Rate in Mice Selected 21 Generations on Alternative Criteria to Increase Litter Size" (1994). Faculty Papers and Publications in Animal Science. 493.

https://digitalcommons.unl.edu/animalscifacpub/493

This Article is brought to you for free and open access by the Animal Science Department at DigitalCommons@University of Nebraska - Lincoln. It has been accepted for inclusion in Faculty Papers and Publications in Animal Science by an authorized administrator of DigitalCommons@University of Nebraska - Lincoln. 


\title{
Uterine Capacity and Ovulation Rate in Mice Selected 21 Generations on Alternative Criteria to Increase Litter Size , $^{12}$
}

\author{
A. C. Clutter*,3, Y. L. Kochera Kirby ${ }^{\dagger, 4}$, and M. K. Nielsen ${ }^{\dagger}$ \\ *Department of Animal Science, Oklahoma State University, Stillwater 74078-0425 and \\ †Department of Animal Science, University of Nebraska-Lincoln, Lincoln 68583-0908
}

\begin{abstract}
After 21 generations of selection for alternative criteria to change litter size in mice, responses in uterine capacity and ovulation rate were evaluated. Females from Generations 22 and 23 were sampled from 12 lines, representing three replicates of four selection criteria: $\mathrm{LS}=$ direct selection on litter size; IX = selection on an index of ovulation rate and the proportion of ova shed that resulted in fully formed offspring; UT = selection on uterine capacity measured as litter size from females unilaterally ovariectomized at $4 \mathrm{wk}$ of age; and $\mathrm{LC}=$ unselected control. All females in the present evaluation (a total of 1,932 ) were unilaterally ovariectomized (either left or right ovary excised) at $4 \mathrm{wk}$, mated at $9 \mathrm{wk}$, and killed at $\mathrm{d} 17$ of gestation. The number of corpora
\end{abstract}

lutea and number of fetuses were counted to measure ovulation rate and uterine capacity, respectively. Selection in $\mathrm{LX}, \mathrm{LS}$, and UT increased $(P<.01)$ ovulation rate from unilaterally ovariectomized females but by a greater amount $(P<.01)$ in IX and LS than in UT. Selection also increased $(P<.01)$ uterine capacity of IX, LS, and UT (average response relative to $\mathrm{LC}=1.76 \mathrm{pups}$ ); response was at least as great in LS and IX as in UT. Direct selection in UT was successful at improving uterine capacity but was no more effective than IX or LS selection. Cases in which ovulation rate limited expression of uterine capacity in UT may have shifted some selection emphasis to ovulation rate and reduced response in uterine capacity.

Key Words: Mice, Selection, Litter Size, Ovulation, Uterus

J. Anim. Sci. 1994. 72:577-583

\section{Introduction}

Litter size is a complex characteristic resulting from many limiting steps. Attempts to describe this complexity in models of components such as ovulation rate and the proportion of ova resulting in fully formed offspring (ova success) or ovulation rate and uterine capacity have brought new understanding. Bradford (1969, 1979) and Johnson et al. (1984) examined the ovulation rate and ova success model in mice and swine, respectively; Bennett and Leymaster (1989, $1990 \mathrm{a}, 1990 \mathrm{~b}$ ) developed the ovulation rate and uterine capacity model in swine. Using mice, alternative selection criteria based on both models have been

\footnotetext{
${ }^{1}$ Journal article of the Oklahoma Agric. Exp. Sta., Oklahoma State Univ., Stillwater 74078-0425.

${ }^{2}$ Published as paper no. 10317, Journal Ser., Nebraska Agric. Res. Div., Univ, of Nebraska, Lincoln 68583-0908.

${ }^{3}$ To whom correspondence should be addressed: 206 Animal Science Building.

${ }^{4}$ Current address: Pediatrics, University of Illinois at Chicago, 840 South Wood, Chicago 60612.

Received May 20, 1993.

Accepted October 13, 1993.
}

explored by Clutter et al. (1990), Gion et al. (1990), and Kirby and Nielsen (1993). The purpose of the present study was to evaluate responses in uterine capacity and ovulation rate of mice due to selection for either uterine capacity, litter size, or an index of ovulation rate and ova success.

\section{Materials and Methods}

Experimental Animals and Protocol. Animals were sampled from a population of mice at the University of Nebraska-Lincoln ( UNL) in which selection for litter size and its components have been studied. The selection criteria, selection applied, and selection responses in litter size through 21 generations have been described most recently by Kirby and Nielsen (1993). The four selection criteria were as follows: 1) $\mathbf{L S}=$ direct selection on number born in unaltered females (i.e., litter size). 2) $\mathbf{X}=$ selection on an index of $I=(9.21 \times$ ovulation rate $)+(21 \times$ ova success $)$. Johnson et al. (1984) gave the rationale for an index of these same components in swine, and Neal et al. (1989) reported responses in swine to selection on an index of these components. 3) UT = selection on 
Table 1. Number of animals measured by selection criterion-side-replicate-generation-location classes

\begin{tabular}{|c|c|c|c|c|c|c|c|c|}
\hline \multirow[b]{3}{*}{ Item and location ${ }^{b}$} & \multicolumn{8}{|c|}{ Criterion $^{\mathbf{a}}$} \\
\hline & \multicolumn{2}{|c|}{ LX } & \multicolumn{2}{|c|}{ LS } & \multicolumn{2}{|c|}{ UT } & \multicolumn{2}{|c|}{$\mathrm{LC}$} \\
\hline & Left & Right & Left & Right & Left & Right & Left & Right \\
\hline \multicolumn{9}{|c|}{ Generation 22 , Replicate 1} \\
\hline OSU & 18 & 18 & 19 & 18 & 22 & 17 & 17 & 21 \\
\hline UNL & 19 & 22 & 25 & 21 & 19 & 21 & 22 & 15 \\
\hline \multicolumn{9}{|c|}{ Generation 22 , Replicate 2} \\
\hline OSU & 22 & 21 & 24 & 22 & 15 & 11 & 18 & 10 \\
\hline UNL & 23 & 22 & 22 & 25 & 22 & 22 & 17 & 25 \\
\hline \multicolumn{9}{|c|}{ Generation 22 , Replicate 3} \\
\hline OSU & 18 & 18 & 14 & 21 & 21 & 21 & 13 & 14 \\
\hline UNL & 16 & 23 & 20 & 20 & 21 & 22 & 23 & 24 \\
\hline \multicolumn{9}{|c|}{ Generation 23, Replicate 1} \\
\hline OSU & 19 & 18 & 16 & 15 & 17 & 17 & 20 & 21 \\
\hline UNL & 21 & 23 & 21 & 18 & 21 & 20 & 22 & 22 \\
\hline \multicolumn{9}{|c|}{ Generation 23 , Replicate 2} \\
\hline OSU & 23 & 24 & 18 & 15 & 14 & 18 & 22 & 15 \\
\hline UNL & 23 & 24 & 29 & 27 & 25 & 24 & 25 & 25 \\
\hline \multicolumn{9}{|c|}{ Generation 23, Replicate 3} \\
\hline OSU & 17 & 20 & 21 & 20 & 17 & 23 & 12 & 12 \\
\hline UNL & 21 & 26 & 20 & 22 & 25 & 25 & 21 & 24 \\
\hline Total & 240 & 259 & 249 & 244 & 239 & 241 & 232 & 228 \\
\hline
\end{tabular}

a IX = index; LS = litter size; UT = uterine capacity; LC = control.

${ }^{\mathrm{b}} \mathrm{OSU}=$ Oklahoma State University, Stillwater; UNL = University of Nebraska-Lincoln.

number born in females unilaterally ovariectomized (right ovary excised) at $4 \mathrm{wk}$ of age. This criterion is designed to select for uterine capacity, defined as the maximum number of offspring the dam can produce when ovulation rate, hence number of viable embryos, is not limiting. Christenson et al. (1987) hypothesized that unilateral hysterectomy-ovariectomy in the pig and the resulting ovarian compensation created a physiological environment in which the number of embryos was not limiting and the number born reflected uterine capacity per uterine horn. Because the duplex uterus in the mouse does not allow transuterine migration of embryos, a simple unilateral ovariectomy resulted in a relatively large number of embryos restricted to a single uterine horn and created a similar model for selection (Clutter et al., 1990). 4) $\mathbf{L C}=$ unselected control.

All four selection criteria were applied in each of three replicates for a total of 12 lines. "Line" in this paper refers to a replicate-criterion population.

Selection ceased after 21 generations and mice sampled for the present study came from Generations 22 and 23 . Unilateral ovariectomy at $4 \mathrm{wk}$ of age was used to measure response in uterine capacity to each of the selection criteria. Within each line and generation, daughters from approximately 30 litters were randomly assigned to either stay in the UNL laboratory or be transported shortly after weaning to the laboratory at Oklahoma State University (OSU). Approximately 40 to 45 females of each line in each generation went to OSU and 40 to 50 females of each line in each generation stayed at UNL. Care was taken to cross-classify location with litter of female. Within location, half of the females underwent leftside ovariectomies and half right-side ovariectomies. Wherever possible, full-sib sisters within a location were assigned ovariectomies on different sides.

The ovariectomized females were assigned to mating cages of three to four females per male at approximately 9 wk of age. Body weights were recorded on the females at this time. Mating assignments were made within line and with maximum avoidance of inbreeding. Evidence of mating plugs was recorded each morning and females were killed at $17 \mathrm{~d}$ of gestation (mating plug $=\mathrm{d} 0$ ). Ovulation rate of the remaining ovary was determined by counting corpora lutea and the number of fully formed fetuses was recorded. Resulting numbers of females per locationline-generation-ovariectomy side ranged from 10 to 29 and the total number of females measured was 1,932 (Table 1).

\section{Data Analysis}

The number of fetuses, number of corpora lutea, ova success (ratio of number of fetuses:number of corpora lutea), and mating weight were analyzed by least squares procedures with a model that included the effects of selection criterion, replicate, generation, location, side (left or right side of the reproductive tract), and all interactions. Replicate effects were considered random, and the effect of criterion was tested using the criterion $\times$ replicate interaction as the error term. This error term includes variation due to drift, which is appropriate for testing responses to 
selection. The effect of side $\times$ criterion was tested with the side $\times$ criterion $\times$ replicate interaction and, because the side $\times$ replicate interaction was not significant, the effect of side was tested with the residual. The number of fetuses, number of corpora lutea, and ova success were also analyzed by side with a model that included the effects of criterion, replicate, generation, location, and all interactions.

Degrees of freedom for criteria effects were partitioned to test the orthogonal comparisons of selection to a control (mean of LS, IX, and UT vs LC), selection for litter size in total to that for the component uterine capacity (mean of LS and IX vs UT) and direct selection for litter size to index selection (LS vs IX).

Exponential functions for number of fetuses on number of corpora lutea were fitted for each sidecriterion-replicate (i.e., data were pooled across generation and location for these analyses). The model fitted using PROC NLIN of SAS (1989) and solved using the multivariate-secant (DUD) method, was as follows:

$$
\mathrm{FET}=\mathrm{B}_{0} *\left(1-\mathrm{B}_{1} * \mathrm{e}^{-\mathrm{B} 2 * \mathrm{CL}}\right)
$$

where FET is number of fetuses, CL is number of corpora lutea, $B_{1}$ and $B_{2}$ are parameters of the exponential function, and $B_{0}$ is interpreted as the maximum number of fetuses and an estimate of uterine capacity per uterine horn (Christenson et al., 1987).

Criteria maxima (estimates of parameter $B_{0}$ ) from these functions were compared using the orthogonol contrasts described above. Standard errors for the comparisons were derived from the variation between replicates for each criterion, and thus account for drift variance.

Two analyses were conducted to evaluate the effectiveness of the unilateral-ovariectomy procedure as a tool for measuring and selecting for uterine capacity. The proportion of females in which number of corpora lutea exceeded number of fetuses was calculated by criterion and side to estimate the frequency with which uterine capacity was fully expressed. Finally, residual correlations between num- ber of fetuses and number of corpora lutea were derived for each criterion after accounting for the effects of replicate, generation and location, to determine whether the ovariectomy procedure reduced the dependency of litter size on ovulation rate. Homogeneity of criteria correlations was tested using methods described by Steel and Torrie (1980).

\section{Results}

Least squares means for number of corpora lutea, number of fetuses, body weight, and ova success are presented by criterion in Table 2 . There was an average effect of selection on ovulation rate (average of LS, IX, and UT vs LC; $P<.01$ ). Response for IX and LS was approximately two ova greater $(P<.01)$ than that for UT. There was also an average effect of selection on uterine capacity as measured by number of fetuses from unilaterally ovariectomized females ( $P$ $<.01$ ). The average uterine capacity of the IX and LS criteria tended to be greater $(P<.10)$ than the UT criterion. Response in body weight was similar to that observed in ovulation rate and uterine capacity. Ova success was greatest in UT and greater $(P<.02)$ than in IX and LS.

Criterion least squares means for number of corpora lutea, number of fetuses, and ova success are presented by side of the reproductive tract in Table 3 . The number of fetuses and ova success were affected by side $(P<.01)$; mean number of fetuses for females with the left or right side intact was 10.09 and 11.12 , respectively. However, ovulation rate was similar for both sides. There was a criterion $\times$ side interaction for number of corpora lutea $(P<.10)$, due to greater side differences for the IX and LC criteria. Although the criterion $\times$ side interaction was not significant for number of fetuses, significance levels of criterion contrasts differed when analyzed by side. There was an average effect of selection on number of fetuses for both the left $(P<.02)$ and right $(P<.001)$ sides, but the average of IX and LS was only greater than that of UT on the right side $(P<.03)$. This was primarily due to the relatively poor performance of IX on the left

Table 2. Least squares means by selection criteria and significance levels of contrasts for the entire data set ${ }^{\mathrm{a}}$

\begin{tabular}{|c|c|c|c|c|c|c|c|}
\hline \multirow[b]{2}{*}{ Characteristic $^{\mathrm{d}}$} & \multicolumn{4}{|c|}{ Criterion $^{b}$ means } & \multicolumn{3}{|c|}{ Significance level of contrast ${ }^{c}$} \\
\hline & IX & $\mathrm{LS}$ & UT & $\mathrm{LC}$ & 1 & 2 & 3 \\
\hline $\mathrm{BW}, \mathrm{g}$ & 27.28 & 27.34 & 25.59 & 24.99 & .02 & .02 & NS \\
\hline FET & 11.01 & 11.56 & 10.57 & 9.29 & .01 & .10 & NS \\
\hline CL & 15.58 & 15.76 & 13.64 & 12.79 & .001 & .001 & NS \\
\hline OS & .712 & .731 & .779 & .731 & NS & .02 & NS \\
\hline
\end{tabular}

a Model = location + generation + replicate + criterion + side + all interactions + residual.

${ }^{\mathrm{b}} \mathrm{IX}=$ index; $\mathrm{LS}=$ litter size; UT = uterine capacity; $\mathrm{LC}=$ control.

cContrast: 1) IX, LS, UT vs LC; 2) IX, LS vs UT; and 3) IX vs LS.

${ }^{d} \mathrm{BW}=$ body weight at mating; FET = number of fetuses; $\mathrm{CL}=$ number of corpora lutea; $\mathrm{OS}=$ ova success = fetuses $/$ corpora lutea. 
Table 3. Least squares means by selection criteria and significance levels of contrasts for traits measured on each side ${ }^{a}$

\begin{tabular}{|c|c|c|c|c|c|c|c|}
\hline \multirow[b]{2}{*}{ Characteristic $^{\mathrm{d}}$} & \multicolumn{4}{|c|}{ Criterion $^{b}$ means } & \multicolumn{3}{|c|}{ Significance level of contrast $\mathrm{c}^{\mathrm{c}}$} \\
\hline & IX & LS & UT & $\mathrm{LC}$ & 1 & 2 & 3 \\
\hline LFET & 10.24 & 11.07 & 10.11 & 8.97 & .02 & NS & .17 \\
\hline RFET & 11.80 & 12.07 & 11.02 & 9.62 & .001 & .03 & NS \\
\hline LCL & 15.45 & 15.73 & 13.63 & 12.90 & .001 & .001 & NS \\
\hline RCL & 15.71 & 15.80 & 13.65 & 12.69 & .001 & .001 & NS \\
\hline LOS & .666 & .707 & .745 & .700 & NS & .06 & .21 \\
\hline ROS & .759 & .766 & .812 & .763 & NS & .01 & NS \\
\hline
\end{tabular}

${ }^{a}$ Model $=$ location + generation + replicate + criterion + all interactions + residual.

$\mathrm{b}_{\mathrm{LX}}=$ index; $\mathrm{LS}=$ litter size; UT = uterine capacity; $\mathrm{LC}=$ control.

cContrast: 1) IX, LS, UT vs LC; 2) IX, LS vs UT; 3) IX vs LS.

${ }^{\mathrm{d}}$ LFET and RFET = number of left- and right-side fetuses; LCL and RCL = number of left- and right-side corpora lutea; LOS and ROS = left- and right-side ova success = fetuses/corpora lutea.

side, which tended $(P=.17)$ to have fewer fetuses than LS.

Exponential functions of number of fetuses on number of corpora lutea for the selection criteria are plotted in Figures 1 and 2 for the left and right sides, respectively. The maximum numbers of fetuses from the parameter $\left(B_{0}\right)$ estimated in the exponential equations are shown in Table 4 for each criterion and side. Significance levels of criterion contrasts, using the variability between replicates as the error, are also listed. These maxima, given the appropriateness of the exponential model, estimate the average uterine capacity. Rankings of criteria maxima (Table 4) were similar to those for mean number of fetuses (Table 3). Although the mean response due to selection (IX, LS, and UT vs LC) was greater on the right than the left side ( 1.89 vs 1.59 fetuses), there was also more variability between replicates in the estimated maxima, hence probability values were less for the left ( $P$ $<.05)$ than the right $(P<.10)$ side. As with mean number of fetuses from the linear-model analyses, maximum number of fetuses from the exponential model was surprisingly low for the IX criterion on the left side.

The frequency of observations in which expression of uterine capacity was not limited by ovulation rate was examined by calculating the proportion of females that had number of corpora lutea exceeding number of fetuses. These proportions are given in Table 5 by side and criterion. The number of corpora lutea exceeded the number of fetuses in greater than $90 \%$ of females from IX and LS, regardless of side of the reproductive tract. The UT and LC females with left side intact usually had number of corpora lutea in excess of number of fetuses, but approximately $20 \%$ of those with right side intact did not.

Table 6 contains the correlations between number of corpora lutea and number of fetuses by criterion and across criteria on the left and right side. The lowest ranking correlation (.26) was found in IX for both measurement on the left and right sides; however, only on the right side was there evidence that the correlations differed among the criteria $(P<$ $.10)$. Overall, the correlation was .31 on the left and .39 on the right.

\section{Discussion}

The ranking of these selection criteria for ovulation rate, measured in unilaterally ovariectomized females, was the same as reported previously for intact females (Gion et al., 1990; Al-Shorepy et al., 1992). Selection, in general, increased number of ova shed, but by a greater amount in LS and IX than in UT. Although it is not known whether the mechanisms for response in

Table 4. Selection-criterion means and significance levels for contrasts of means of maximum number of fetuses from exponential model using number of corpora lutea

\begin{tabular}{|c|c|c|c|c|c|c|c|}
\hline \multirow[b]{2}{*}{ Characteristic $^{c}$} & \multicolumn{4}{|c|}{ Criterion $^{\mathrm{a}}$ means } & \multicolumn{3}{|c|}{ Significance level of contrast ${ }^{b}$} \\
\hline & IX & LS & UT & LC & 1 & 2 & 3 \\
\hline LFET & 10.94 & 12.26 & 11.64 & 10.02 & .05 & NS & .20 \\
\hline RFET & 12.79 & 13.41 & 12.15 & 10.89 & .10 & .20 & NS \\
\hline
\end{tabular}

${ }^{\text {a IX }}$ = index; LS = litter size; UT = uterine capacity; LC = control.

bContrast: 1) IX, LS, UT vs LC; 2) IX, LS vs UT; 3) IX vs LS.

${ }^{\mathrm{C}} \mathrm{LFET}$ and RFET $=$ number of left- and right-side fetuses. 


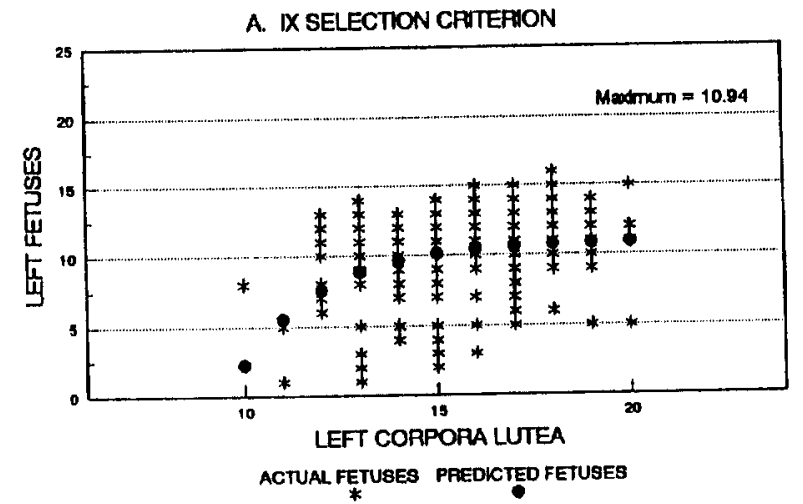

B. LS SELECTION CRITERON

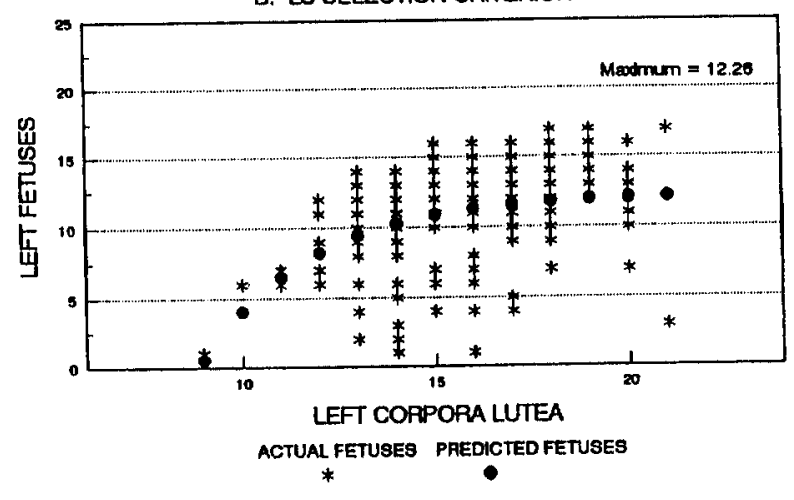

C. UT SELECTION CRIERRION

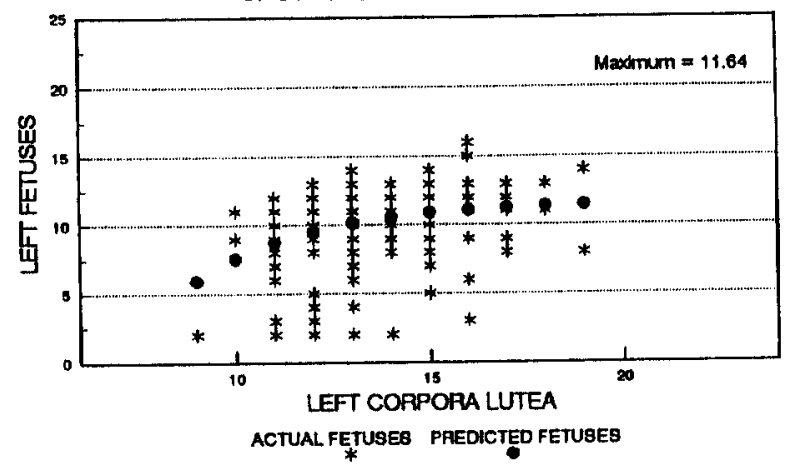

D. LC SELECTION CRITERION

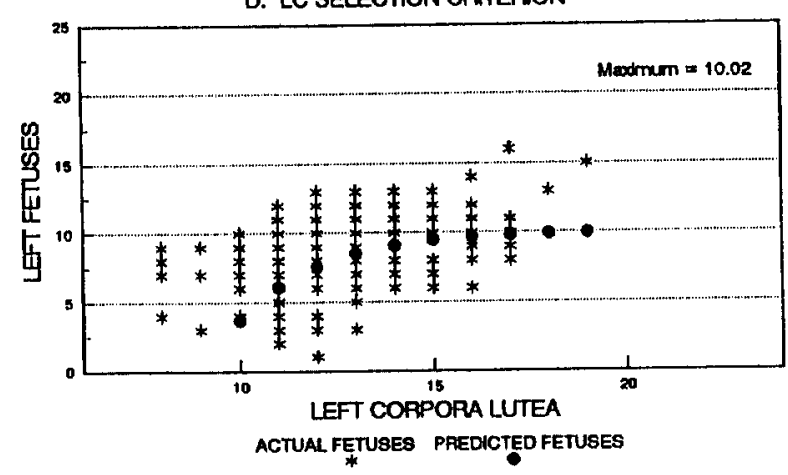

Figure 1. Relationship between number of fetuses and number of corpora lutea by selection criteria $/ \mathrm{A}=$ IX: index, B = LS: litter size, $\mathrm{C}=\mathrm{UT}$ : uterine capacity, $\mathrm{D}=\mathrm{LC}$ : control) observed on the left side in females that had been unilaterally (right) ovariectomized. Data points for actual fetuses on the graphs may represent more than one observation.
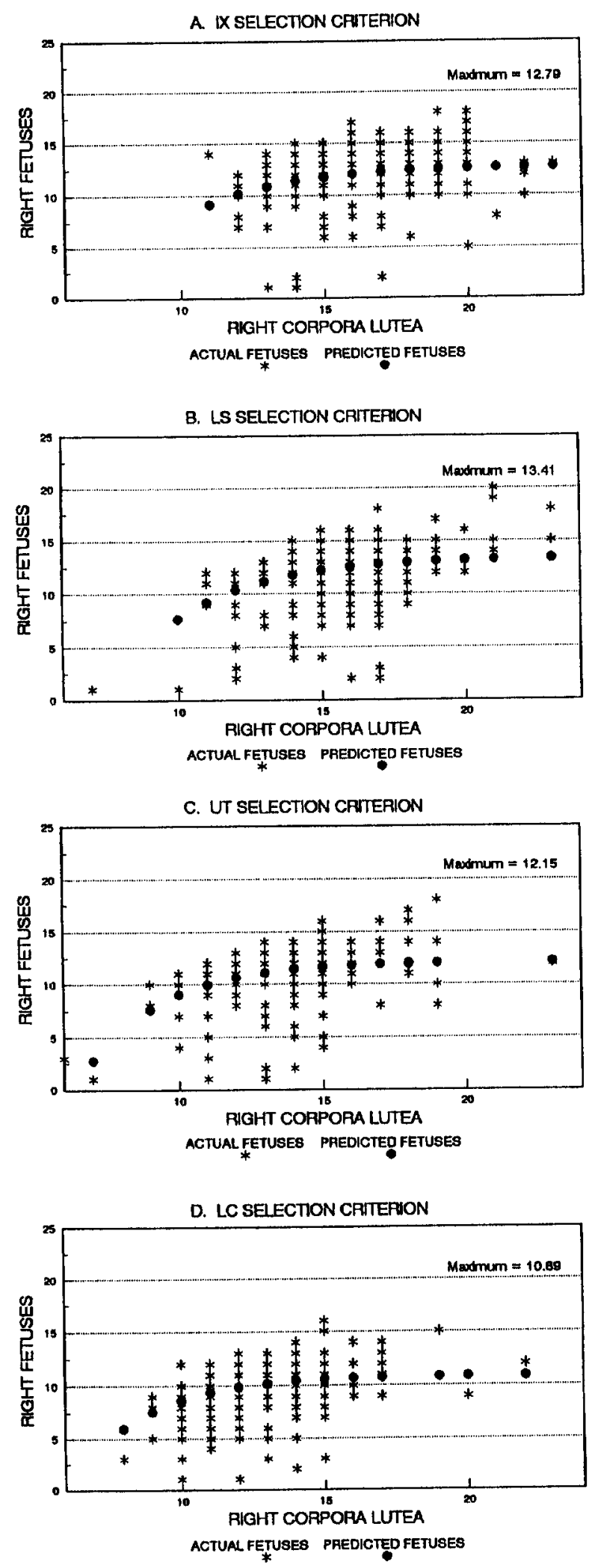

Figure 2. Relationship between number of fetuses and number of corpora lutea by selection criteria $\mid \mathrm{A}=$ IX: index, $\mathrm{B}=\mathrm{LS}$ : litter size, $\mathrm{C}=\mathrm{UT}$ : uterine capacity, $\mathrm{D}=\mathrm{LC}$ : control) observed on the right side in females that had ben unilaterally (left) ovariectomized. Data points for actual fetuses on the graphs may represent more than one observation. 
Table 5. Proportion of observations for which expression of uterine capacity could not have been limited by ovulation rate $^{\mathrm{a}}$

\begin{tabular}{lcc}
\hline \hline & \multicolumn{2}{c}{ Side intact } \\
\cline { 2 - 3 } Criterion $^{\mathrm{b}}$ & Left & Right \\
\hline IX & .97 & .92 \\
LS & .94 & .93 \\
UT & .91 & .79 \\
LC & .93 & .84 \\
\hline
\end{tabular}

a Number of fetuses was less than the number of corpora lutea. $\mathrm{b}_{\mathrm{IX}}$ = index; LS = litter size; UT = uterine capacity; LC = control.

ovulation rate expressed by intact and unilaterally ovariectomized females were the same, the criteria rankings were not altered by the ovariectomy treatment. These rankings are consistent with the objective of LS and IX that results in selection pressure on ovulation rate. The UT criterion is intended to select only for uterine capacity, but it seems some emphasis was unintentionally directed toward ovulation rate.

Direct selection for uterine capacity in UT was successful. Realized heritability for this selection criterion can be estimated from these data by dividing the difference in number of fetuses for UT and LC in the present study by the difference in corresponding cumulative selection differentials for UT and LC. That ratio, using the criteria means for number of fetuses in Table 2 and the cumulative selection differentials for UT and LC reported by Kirby and Nielsen (1993), is $(10.57-9.29) /(28.53-3.28)=.05$. The estimate of realized heritability in 21 generations of selection was .08 (Kirby and Nielsen, 1993).

Selection for the LS and IX criteria was also effective for improving genetic merit for uterine capacity; in fact, response in LS and IX tended to exceed that of UT. Direct selection for litter size in LS would be expected to put some emphasis on uterine capacity, as would IX through selection for ova success, but these criteria must also address ovulation rate. Thus, selection in UT was expected to be most effective at improving uterine capacity.

A greater number of fetuses produced on the right than on the left side of the reproductive tract was consistent with results for intact females from this (Clutter et al., 1990; Gion et al., 1990) and other mouse populations (Falconer et al., 1961, and Wiebold and Becker, 1987) in which the right side of the tract is most productive.

Al-Shorepy et al. (1992) have reported data on preimplantation embryonic development, and Nielsen et al. (1992) have presented data on uterine mass and uterine blood volume in the same lines of mice. Selection (LS, IX, and UT vs LC) advanced the mean stage of embryonic development, measured at $3.5 \mathrm{~d}$, in the left horn; a similar shift in mean stage, but not significant, was observed in the right horn. Variability in stage of embryonic development within the right uterine horn was reduced due to selection (LS, IX, and UT vs LC). Uterine mass and uterine blood volume at d 3 and 6 of gestation were increased by selection (LS, IX, and UT vs LC), whereas the ratio of uterine blood: mass was not; uterine mass:body mass tended to be higher after selection. Differences in uterine capacity with selection may be partly explained by the larger uterine mass and volume of blood and more uniform, faster embryonic development.

Christenson et al. (1987) defined uterine capacity in the pig to include only those factors from $\mathrm{d} 30$ to term of gestation (i.e., post-implantation) that affect number of offspring per litter. In contrast, we have considered uterine capacity in the mouse under a broader definition, one that also includes factors affecting survival, development, and implantation rate of embryos after they enter the uterus. Full expression of uterine capacity, as defined here, is only possible when the number of potentially viable embryos entering the uterus is at least as great as capacity. Number of viable embryos at that stage is primarily a function of ovulation rate, but also fertilization rate and survival through the oviduct. To estimate the frequency with which uterine capacity was fully expressed, we have assumed that number of ova shed must have exceeded number of fetuses by at least one to have allowed full expression. The number of ova exceeded number of fetuses in the majority of observations, but a relatively small proportion of females were probably limited by ovulation rate. This proportion was greatest for those groups with lower mean ovulation rate, especially when measured on the right side. To the extent that ovulation rate was limiting more frequently for UT and LC in the present evaluation, the estimates of uterine capacity from mean number of fetuses for those groups may have been biased downward. However, maxima criteria from the exponential functions should have been relatively free of any such bias and were ranked similarly to the criteria means for number of fetuses.

In cases in which ovulation rate limited expression of uterine capacity during selection in UT, selection emphasis would have been shifted from uterine

Table 6. Residual correlations by side between number of fetuses and number of corpora lutea ${ }^{a}$

\begin{tabular}{lcc}
\hline \hline Criterion $^{\mathrm{b}}$ & Left & Right \\
\hline IX & .26 & .26 \\
LS & .33 & .45 \\
UT & .31 & .41 \\
LC & .38 & .43 \\
Overall & .31 & .39 \\
\hline
\end{tabular}

${ }^{\text {a }}$ Model = location + generation + replicate + interactions.

$\mathrm{b}_{\mathrm{IX}}=$ index; $\mathrm{LS}=$ litter size; UT = uterine capacity; $\mathrm{LC}=$ control. 
capacity to ovulation rate. This may explain the response in ovulation rate to selection in UT, even though the expectation for the UT criterion was selection for only uterine capacity. This may also explain why UT was no more effective than LS or IX at improving genetic merit for uterine capacity.

Christenson et al. (1987) reported a phenotypic correlation near zero between ovulation rate and number of fetuses in unilaterally hysterectomizedovariectomized gilts. They concluded that selection for litter size in these gilts would be essentially independent of ovulation rate and, thus, would improve genetic merit for uterine capacity. Clutter et al. (1990) reported phenotypic correlations between numbers of corpora lutea and fetuses of .57 on the left and .70 on the right side in intact females from the base generation of the present population. Clearly, unilateral ovariectomy has resulted in a greater independence between ovulation rate and number of fetuses, but the correlation is still greater than zero. The uterine/placental anatomy of the mouse may make it more difficult to challenge uterine capacity by increasing ovulation rate.

\section{Implications}

Selection for number born from unilaterally ovariectomized females was an effective method for improving genetic merit for uterine capacity in the mouse. Inability to allow full expression of uterine capacity in all females may have reduced direct response to this selection method relative to methods of selection for total litter size. Procedures that restrict uterine space to reveal variation in capacity may be more effective in the pig than in the mouse.

\section{Literature Cited}

Al-Shorepy, S. A., A. C. Clutter, R. M. Blair, and M. K. Nielsen. 1992. Effects of three methods of selection for litter size in mice on pre-implantation embryonic development. Biol. Reprod. 46: 958.
Bennett, G. L., and K. A. Leymaster. 1989. Integration of ovulation rate, potential embryonic viability and uterine capacity into a model of litter size in swine. J. Anim. Sci. 67:1230.

Bennett, G. L., and K. A. Leymaster. 1990a. Genetic implications of a simulation model of litter size in swine based on ovulation rate, potential embryonic viability and uterine capacity: I. Genetic theory. J. Anim. Sci. 68:969.

Bennett, G. L., and K. A. Leymaster. 1990b. Genetic implications of a simulation model of litter size in swine based on ovulation rate, potential embryonic viability and uterine capacity: II. Simulated selection. J. Anim. Sci. 68:980.

Bradford, G. E. 1969. Genetic control of ovulation rate and embryo survival in mice. Genetics 61:905.

Bradford, G. E. 1979. Genetic variation in prenatal survival and litter size. Proc. XIII Biennial Symp. on Anim. Reprod. J. Anim. Sci. 49(Suppl. 2):66.

Christenson, R. K., K. A. Leymaster, and L. D. Young. 1987. Justification of unilateral hysterectomy-ovariectomy as a model to evaluate uterine capacity in swine. J. Anim. Sci. 65:738.

Clutter, A. C., M. K. Nielsen, and R. K. Johnson. 1990. Alternative methods of selection for litter size in mice: I. Characterization of base population and development of methods. J. Anim. Sci. 68:3536

Falconer, D. S., R. G. Edwards, R. E. Fowler, and R. C. Roberts. 1961. Analysis of differences in the number of eggs shed by the two ovaries of mice during natural oestrus or after superovulation. J. Reprod. Fertil. 2:418.

Gion, J. M., A. C. Clutter, and M. K. Nielsen. 1990. Alternative methods of selection for litter size in mice: II. Response to thirteen generations of selection. J. Anim. Sci. 68:3543.

Johnson, R. K., D. R. Zimmerman, and R. J. Kittok. 1984. Selection for components of reproduction in swine. Livest. Prod. Sci. 11: 541.

Kirby, Y. K., and M. K. Nielsen. 1993. Alternative methods of selection for litter size in mice: III. Response to generations of selection. J. Anim. Sci. 71:571.

Neal, S. M., R. K. Johnson, and R. J. Kittok. 1989. Index selection for components of litter size in swine: Response to five generations of selection. J. Anim. Sci. 67:1933.

Nielsen, M. K., R. J. Kittok, and Y.L.K. Kirby. 1992. Uterine mass and uterine blood volume in mice selected 21 generations on alternative criteria to increase litter size. J. Anim. Sci. 70(Suppl. 1):146(Abstr.).

SAS. 1989. SAS/STAT ${ }^{\circledR}$ User's Guide (4th Ed.). SAS Inst. Inc., Cary, NC.

Steel, R.G.D., and J. D. Torrie. 1980. Principles and Procedures of Statistics: A Biometrical Approach (2nd Ed.). McGraw-Hill Book Co., New York.

Wiebold, J. L., and W. C. Becker. 1987. Inequality in function of the right and left ovaries and uterine horns of the mouse. J. Reprod. Fertil. 79:125. 